Ivana Janjić ${ }^{1}$

Milica Jovanović ${ }^{2}$

Innovation Center, University of Niš

Zoran Simonović ${ }^{3}$

Institute of Agricultural Economics Belgrade
P. $19-28$

SCIENTIFIC REVIEW PAPER

DOI: $10.5937 / E S D 2102019 J$

Received: April 15, 2021

Accepted: May 12, 2021

\title{
THE IMPORTANCE OF RESEARCH AND DEVELOPMENT FOR INNOVATIVE ACTIVITY: THE OVERVIEW OF THE TOP COUNTRIES IN EUROPE AND WORLDWIDE
}

\begin{abstract}
In the conditions of economic globalization and a dynamic business environment, companies need to continuously improve and innovate their business, in order to avoid complex and fierce competition and to achieve long-term and sustainable success. Due to the intensive effect of technical and technological progress, the survival and success of the company on the market depends on the introduction of innovative changes in the company and the undertaking of research and development activities. Research and development activities are a crucial factor in generating knowledge, creating patents and innovations, as well as in the increasing of profitability in the business of modern companies. Research and development $(R \& D)$ and innovations are considered to be a cornerstone of competitive advantage. The object of this paper is to point out the vital importance that $R \& D$ has for innovativeness, i.e. for performing innovative activities at the level of European countries and worldwide.
\end{abstract}

Keywords: research and development, $R \& D$ expenditures, patents, innovativeness

JEL classification: 032

\section{ЗНАЧАЈ ИСТРАЖИВАҢА И РАЗВОЈА ЗА ИНОВАТИВНУ АКТИВНОСТ: ПРЕГЛЕД НАЈБОЉИХ ЗЕМАЉА У ЕВРОПИ И СВЕТУ}

\section{Апстракт}

У условима економске глобализације и динамичког окружења, компаније морају континуирано да унапређују и иновирају своје пословање, како би избегле сложену и оштру конкуренцију и како би оствариле дугорочан успех. Услед интезивног дејства техничко-технолошког прогреса, од увођена иновативних промена у предузећу и предузимања активности истраживања и развоја, зависи опстанак и успех предузећа на тржишту. Активности истраживања и развоја представљају круцијалан фактор у генерисању

\footnotetext{
1.ivana91.ekfak@gmail.com, ORCID ID 0000-0003-3142-8467

2 jovanovicmilicaa90@gmail.com, ORCID ID 0000-0002-6410-0938

${ }^{3}$ zoki@medianis.net, ORCID ID https://orcid.org/0000-0002-2769-6867
} 
знања, креирању патената и иноващија, као и у расту рентабилности у пословању савремених предузећа. Стога, истраживање и развој и иновачије представљају камен темељац конкурентске предности. Сврха овог рада је да укаже на виталан значај који истраживање и развој има за иновативност, тј. за обављање иновативних активности на нивоу земаљ у у Еропи и у свету.

Кључне речи: истраживање и развој, трошкови истраживања и развоја, патенти, иновативност

\section{Introduction}

The knowledge economy is a stage in the development of the world economy in which knowledge, i.e. intellectual resources, in particular, are marked as a key determinant for building and maintaining competitive advantages (Krstić, Rađenović, 2019, p. 11; Jovanović, Petrović, Janjić, 2021). In the era of fast technological advancement, characterized by an intensive process of globalization and the changing world, companies are facing the rise of new competitors and the heterogeneity of demand.

The creative potential of companies relies not only on their ability to establish operational strategies for innovation management, but also on their possibility to perform research and development (R\&D) activities, as their internal competencies. In the information age of the $21^{\text {st }}$ century and today's competitive landscape, timely and adequate firms' investments in $\mathrm{R} \& \mathrm{D}$ and innovative activities will provide a competitive advantage and their sustainability. In modern market conditions, harsh competition does not forgive mistakes, thus, innovation activities are seen as one of the most important factors in maintaining a competitive knowledge-based economy (Janjić, Rađenović, 2019).

R\&D and innovations ensure the base of technical and scientific solutions, needed to overcome global societal challenges, contributing to a well-functioning knowledgebased economy. R\&D investments stimulate creativity and innovations, resulting in the creation of new technology, knowledge, concepts, ideas and expertise. The higher amount of resources allocated to $R \& D$ (R\&D input) has impacts on higher R\&D output, measured by the number of patent applications (Chiesa, Masela, 1996), which ultimately affects the innovation activity.

\section{The importance of $R \& D$ activities for the companies}

In the conditions of the universal effect of technical-technological progress and increasingly fierce competition, to reach higher standards of performance and to overcome competition and risks, companies must invest in R\&D activities. The key source to expand knowledge and to functionalize new technologies is R\&D as a systematical concept (Tether, 2005). R\&D entails increasing the knowledge base and applying that knowledge in developing new and enhancing existing products and processes.

Managing $R \& D$ activities represents a major strategic factor in generating future development that will ultimately benefit (material and intangible benefits) the company 
and lead to sustainable profits. In generating future growth and development and longterm profits, managing $\mathrm{R} \& \mathrm{D}$ activities is a crucial strategic factor. Companies can obtain patents through the invention of new products by introducing and controlling R\&D operations, establishing a competitive advantage and gaining a stronghold in the marketplace. By improving the process that is used, successful R\&D can reduce the cost of producing products, thus ensuring companies to be more competitive than their competition and contributing to an increase in profit margins. The raising of funds to improve R\&D operations is an excellent way to build a structure that enables companies to be innovative and to illustrate the vision of organizations to its investors. Companies will become more innovative if they attract, recruit and hire talented human resources, bearing in mind that internal $\mathrm{R} \& \mathrm{D}$ depends on the availability and quality of human capital.

Internal and external $R \& D$ activities are generally recognized as the drivers of technological development, while R\&D investments are considered to be a reliable measure of innovative potential. In order to encourage their "absorptive capacity" as a source of productivity growth, companies have to implement internal R\&D activities (Romer, 1990). Investing in internal R\&D activities engages companies in a process of learning, encouraging and fostering the development of new products or processes, as well as, in many cases, the growth of new markets (Griffith et al. 2004). Investments in $R \& D$ within an enterprise create the integrative skills needed to deploy information resources. R\&D is essential for gathering external information and expertise, ensuring that companies' proportion of high novelty products grows (Barton, 1992; Mathews, 2003). Companies may achieve synergies from their R\&D mix when they use internal and external sources of $R \& D$ at the same time. It is crucial to point out that new products reflect the future commercial value of the R\&D activities (Katila, Ahuja, 2002, p. 1183) of an organization and are predominantly affected by the decision of knowledge sourcing.

\section{R\&D as a determinant of innovativeness}

Intense global competition, rapid technological change and increased sophistication of consumers, force companies to continuously invest in R\&D and innovation, which are considered as the key strategic factor for the prosperity of companies (Marković, Krstić, Rađenović, 2020). For an effective innovation process, it is critical to have the capability of R\&D, where it should be noted that research and technological development predate innovation as a preliminary step. Innovations are the result of proactive research and development in the company. $\mathrm{R} \& \mathrm{D}$ has long been regarded as a measure of innovation and strategic growth lever for companies, aiming to achieve "world-class" and market supremacy (Hendry, 1998).

According to Mansfield (1980) and Griliches (1986), R\&D spending is positively related to a company's innovative potential, which is reflected in productivity growth. In order to achieve a radical innovation, Laursen and Salter (2006) proposed that an organization often needs to make a substantial investment in R\&D, including a lower probability of success but higher performance. Since the current R\&D investment is often the result of previous R\&D spending, some researchers (Garcia, Navas, 2007) indicated that $R \& D$ may reflect on the company's creative potential and superior performance. 
In this context, the most significant input for generating knowledge and creativity is R\&D spending (Huergo, 2006), supposing that the greater investment in R\&D affects the higher possibility of success in technological innovation. R\&D is an important driver of technology diffusion since it reduces the likelihood of product innovations being rejected or unproductive innovations being implemented (Bolton, Harris, 1999). Technological innovation can be recognized as the process of "generation, application and diffusion of techno-scientific knowledge" (Nieto, 2001) and as a set of R\&D activities related to the production of innovations. As a result of research and development, the invention is regarded as the first scientific knowledge emerging from technology or applied science (Nieto, 2001; Hill, Rothaermel, 2003).

Figure 1: Technological innovation process

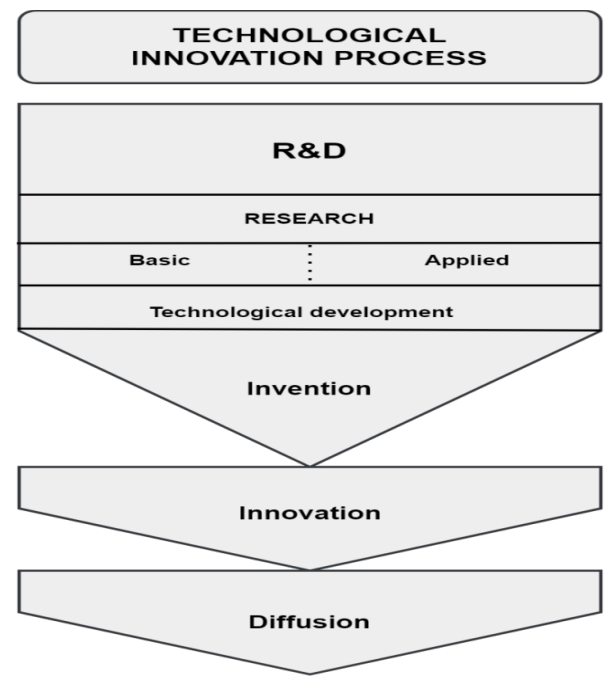

Source: Adapted to Nieto (2001, p. 61)

Since a company's ability to innovate is dependent on its R\&D function and technological capabilities, efficient innovation is not guaranteed (Tsai, 2005). Great technological and inventive potential, does not always ensure the successful commercialization of products (Fleming, 2002, p. 1064).

\section{3. $R \& D$ input and $R \& D$ output as preconditions of innovative activity}

In theory, the existence of a causal association between R\&D investment and innovation dates back to the 1980s. Many economists have begun to emphasize the importance of $R \& D$ expenditures ( $R \& D$ input) and patents ( $\& D$ output) as measures in boosting innovations and economic growth (Geroski, Mazzucato, 2002). R\&D expenditures are one of the most commonly used indicators of innovation input. The $R \& D$ intensity ( $R \& D$ expenditures as a percentage of GDP) can be used to measure the relative degree of investment in generating new knowledge. 
Table 1 shows the top 10 countries in Europe by R\&D expenditures as a share of GDP, during the period from 2012 to 2019. The following countries are presented: Sweden, Austria, Germany, Denmark, Belgium, Finland, Norway, France, the Netherlands and Slovenia. During the eight years, the results showed that Sweden had the leading position from 2015 to 2019 (3.22\% in 2015, 3.25\% in 2016, 3.36\% in 2017, 3.32\% in 2018 and $3.39 \%$ in 2019) while only Finland had better results in $2012(3.4 \%)$, in $2013(3.27 \%)$ and $2014(3.15 \%)$ than Sweden in the same years.

Table 1: The Top 10 countries in Europe by Research and Development Expenditures 2012-2019 (\% GDP)

\begin{tabular}{|l|c|c|c|c|c|c|c|c|}
\hline \multirow{2}{*}{ Country } & \multicolumn{7}{|c|}{ Year } \\
\cline { 2 - 10 } & 2012 & 2013 & 2014 & 2015 & 2016 & 2017 & 2018 & 2019 \\
\hline Sweden & 3.23 & 3.26 & 3.1 & 3.22 & 3.25 & 3.36 & 3.32 & 3.39 \\
\hline Austria & 2.91 & 2.95 & 3.08 & 3.05 & 3.12 & 3.06 & 3.14 & 3.19 \\
\hline Germany & 2.88 & 2.84 & 2.88 & 2.93 & 2.94 & 3.05 & 3.12 & 3.17 \\
\hline Denmark & 2.98 & 2.97 & 2.91 & 3.06 & 3.09 & 3.03 & 3.02 & 2.96 \\
\hline Belgium & 2.28 & 2.33 & 2.37 & 2.43 & 2.52 & 2.67 & 2.67 & 2.89 \\
\hline Finland & 3.4 & 3.27 & 3.15 & 2.87 & 2.72 & 2.73 & 2.76 & 2.79 \\
\hline Norway & 1.63 & 1.65 & 1.78 & 1.94 & 2.04 & 2.1 & 2.06 & 2.22 \\
\hline France & 2.23 & 2.24 & 2.23 & 2.27 & 2.22 & 2.2 & 2.2 & 2.19 \\
\hline Netherlands & 1.19 & 2.16 & 2.17 & 2.15 & 2.15 & 2.18 & 2.14 & 2.16 \\
\hline Slovenia & 2.56 & 2.56 & 2.37 & 2.2 & 2.01 & 1.87 & 1.96 & 2.04 \\
\hline
\end{tabular}

Source: Prepared by the authors, based on the data from EUROSTAT

Observing the results from Table 1, it can be concluded that Sweden invests in R\&D more than any other country, and the global trend in R\&D expenditures is growing year after year. In 2019, the high R\&D investments were recorded also in Austria (3.19\%), followed by Germany (3.17\%). All R\&D expenditures above 3\% of GDP in 2019 were ahead of Denmark $(2.96 \%)$, Belgium (2.89\%), Finland (2.79\%), Norway (2.22\%), France (2.19\%), Netherlands (2.16\%) and Slovenia (2.04\%). The R\&D expenditures below $2 \%$ of GDP, were registered: Norway (1.63\% in 2012; $1.65 \%$ in 2013; $1.78 \%$ in 2014 and $1.94 \%$ in 2015), the Netherlands (1.19\% in 2012) and Slovenia (1.87\% in 2017 and 1.96\% in 2018).

Innovative capacity on the national level may be improved by fostering investments in R\&D. Table 2 and Figure 2, show the group of countries on the global level which invested most in R\&D in 2020. The R\&D intensity, i.e. R\&D expenditure as a percentage of GDP, was much lower in the EU than in South Korea (4.35\% in 2020), Israel (4.04\% in 2020) and Japan (3.28\% in 2020), while R\&D intensity in Germany and the United States of America was at about the same level. 
Table 2: The Top 10 countries Worldwide by Research and Development Expenditure in 2020 (\%GDP)

\begin{tabular}{|c|c|}
\hline Country & Year (2020) \\
\hline South Korea & 4.35 \\
\hline Israel & 4.04 \\
\hline Finland & 3.5 \\
\hline Japan & 3.28 \\
\hline Sweden & 3.0 \\
\hline Denmark & 3.0 \\
\hline Austria & 2.98 \\
\hline Switzerland & 2.97 \\
\hline Germany & 2.84 \\
\hline United States of America & 2.84 \\
\hline
\end{tabular}

Source: Prepared by the authors, based on the data from Statista, https://www.statista.com/ statistics/732269/worldwide-research-and-development-share-of-gdp-top-countries/

The number of patent applications is regarded as a valuable indicator for assessing a company's innovative capability (Wakasugi, Koyata, 1997), and serves as a way to protect intellectual property rights. Historically, the relationship between a company's $R \& D$ investment and patenting activity has been at the core of many empirical analyses.

Figure 2: Graphical representation of the leading countries in $R \& D$ expenditures as a share of GDP worldwide in 2020

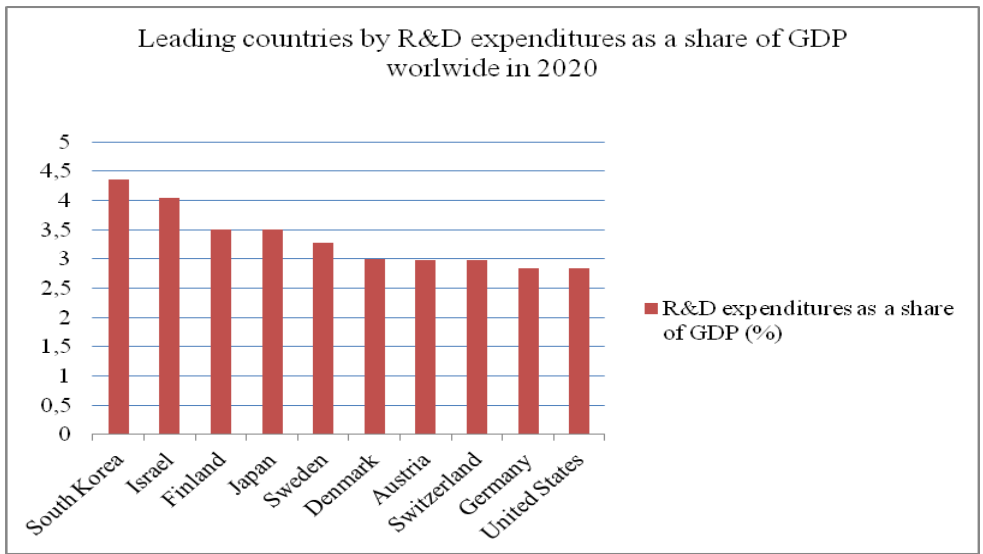

Source: Elaborated by the authors based on the data from Table 2

Some empirical research found a strong relationship between R\&D spending and the number of patents (Pakes, Griliches, 1984; Bound et al.1984; Hall et al. 1986). In the study of chemical and computer industries, some researchers (Ahuja, Katila, 2001; Hagedoorn, Duysters, 2002) proved a strong correlation between R\&D investments and patents as an R\&D output. Cardinal and Hatfield (2000) concluded that a greater focus on $\mathrm{R} \& \mathrm{D}$ spending was a key factor in generating productive inventions, measured by patents. 
Table 3: The geographic origin of patent application

\begin{tabular}{|c|c|}
\hline Country & $2019(\%)$ \\
\hline US & $25 \%$ \\
\hline Germany & $15 \%$ \\
\hline Japan & $12 \%$ \\
\hline China & $7 \%$ \\
\hline France & $6 \%$ \\
\hline Switzerland & $5 \%$ \\
\hline Republic of Korea & $5 \%$ \\
\hline Netherlands & $4 \%$ \\
\hline UK & $3 \%$ \\
\hline Sweden & $2 \%$ \\
\hline
\end{tabular}

Source: European Patent Office - Patent index 2019

The data presented in Table 3 and Figure 3, show the number of patent applications, determined by the geographic origin at the world level. The results showed that more than half of all patent applications came from companies grounded in Europe. In 2019, the total number of patent applications in Europe (30\%) was higher compared with the total number of patent applications in the US (25\%), Japan (12\%), China (7\%), the Republic of Korea (5\%) and the UK (3\%).

Table 4: The most Innovative Economies in the World in 2020

\begin{tabular}{|c|c|c|c|}
\hline Country & Score (0-100) & Rank & $\begin{array}{c}\text { Rank change to } \\
\text { previous year }\end{array}$ \\
\hline Switzerland & 66.08 & 1 & +0 \\
\hline Sweden & 62.47 & 2 & +0 \\
\hline United States of America & 60.56 & 3 & +0 \\
\hline United Kingdom & 59.78 & 4 & +1 \\
\hline Netherlands & 58.76 & 5 & -1 \\
\hline Denmark & 57.53 & 6 & +1 \\
\hline Finland & 57.02 & 7 & -1 \\
\hline Singapore & 56.61 & 8 & +1 \\
\hline Germany & 56.55 & 9 & -1 \\
\hline Republic of Korea & 56.11 & 10 & +1 \\
\hline
\end{tabular}

Source: WIPO - Global Innovation Index 2020

According to the World Intellectual Property Organization (WIPO), which released the Global Innovation Index 2020 (GII), Switzerland is an innovation leader, with a high rank (66.08/at the first place out of 131 countries). After Switzerland, the top-performing economies are: 1) Sweden with GII of 62.47 and at the second place out of 131 countries; 2) the United States of America with a GII of 60.56 and at the third place out of 131 countries; 3 ) the United Kingdom with GII 59.78 and at the fourth place out of 131 countries and 4) the Netherlands with GII 58.76 at the fifth place out of 131 countries ranked in 2020. In the top 10 global ranking economies, for their innovation 
environments and outputs, the leading positions in 2020 also belonged to: Denmark (57.53/at the sixth place out of 131), Finland (57.02/at the seventh place out of 131), Singapore (56.61/at the eighth place out of 131), Germany (56.66/at the ninth place out of 131) and the Republic of Korea (56.11/at the tenth place out of 131).

\section{Conclusion}

In the past, tangible assets were the most valuable company resources. Nowadays, intellectual resources are the fundamental generator of a company's success (Petković, Krstić, Rađenović, 2020). The progress of new technologies, R\&D and innovations are the engines of knowledge-based economies. At the firm, national and regional level, $R \& D$ investments and innovations are the main drivers of increased competitiveness. In highly competitive environments, companies' ability to build and retain market share, as well as increase firm profitability, is based on their R\&D capabilities. R\&D efforts can be viewed as a foundational activity that fosters creativity, as well as a valuable source of innovation for their manufacturing processes and strategic decisions.

$\mathrm{R} \& \mathrm{D}$ is deemed to create an organizational climate that favours developing new products and manufacturing process, and new core competencies through invention and innovation. The innovations and $\mathrm{R} \& \mathrm{D}$ are two different concepts, which complement each other. $R \& D$ is the method to achieve a target or outcome, while innovation refers to a new goal or result. Thus, $R \& D$ is the precondition of innovation activity, since it provides the necessary knowledge and experience for innovation.

In order to evaluate the productivity impact of inventions, the most commonly used proxy measures of creative activity and indices of firm technical capabilities are $R \& D$ expenses (R\&D input) and patents ( $\& \& D$ output). R\&D expenses can be observed as an indicator of the resources dedicated to the innovation process, needed to launch new technologies, products and processes to the market. Patent as an R\&D output has long been considered as a key factor in fostering innovations by allowing inventors to profit from their inventions. The company ability to generate a higher number of patent applications depends on the realization of R\&D activities, but does not depend on R\&D spent by competitors.

\section{References}

Ahuja, G., Katila, R. (2001). Technological Acquisition and the Innovative Performance of Acquiring Firms: A Longitudinal Study. Strategic Management Journal, 22(3), 197-220.

Barton, L. (1992). Core capabilities and core rigidities: A paradox in managing new product development. Strategic Management Journal, 13(1), 111-125.

Bolton, P., Harris, C. (1999). Strategic experimentation. Econometrica, 67(2), 349-374.

Bound, J., Cummins, C., Griliches, Z., Hall, B.H., Jaffe, A. (1984). Who Does R\&D and Who Patents? In: Griliches, Z. (Ed.), Patents and Productivity, Chicago: University of Chicago Press, 21-54. 
Cardinal, L.B., Hatfield, D.E. (2000). Internal Knowledge Generation: The Research Laboratory and Innovative Productivity in the Pharmaceutical Industry. Journal of Engineering \& Technology Management, 17(3-4), 247-271.

Chiesa, V., Masella, C. (1996). Searching for an effective measure of R\&D performance. Management Decision, 34(7), 49-57.

European Patent Office. (2019). Patent Index 2019. Germany: Munich

EUROSTAT. (2019). Gross domestic expenditure on $R \& D$ (GERD) as \% GDP. Publications Office of the European Union, Luxembourg.

Fleming, L. (2002). Finding the Organizational Sources of Technological Breakthroughs: The Story of Hewlett-Packard's Thermal Ink-Jet. Industrial\& Corporate Change, 11(5), 1059-1084.

García, F., Navas, J. E. (2007). Explaining and Measuring Success in New Business: The Effect of Technological Capabilities on Firm Results. Technovation, 27(1), $30-46$.

Geroski, P., Mazzucato, M. (2002). Learning and the Sources of Corporate Growth. Industrial and Corporate Change, 11(4), 623-644.

Griffith, R., Redding, S., Van, R.J. (2004). Mapping the two faces of R\&D: Productivity growth in a panel of OECD industries. Review of Economics and Statistics, 86(4), 883-895.

Griliches, Z. (1986). Productivity, R\&D, and Basic Research at the Firm Level in the 1970s. American Economic Review, 76(1), 141-154.

Hagedoorn, J., Duysters, G. (2002). The Effect of Mergers and Acquisitions on the Technological Performance of Companies in a High-Tech Environment. Technology Analysis and Strategic Management, 14(1), 67-85.

Hall, B.J., Griliches, Z., Hausman, J.A. (1986). Patents and R\&D: Is There a Lag? International Economic Review, 27(2), 265- 283.

Hendry, L.C. (1998). Applying world-class manufacturing to make-to-order companies: problems and solutions. International Journal of Operations\&Production Management, 18(11), 1086-1100.

Hill, C.W.L., Rothaermel, F.T. (2003). The Performance of Incumbent Firms in the Face of Radical Technological Innovation. Academy of Management Review, 28(2), 257-274.

Huergo, E. (2006). The Role of Technological Management as a Source of Innovation: Evidence from Spanish Manufacturing Firms. Research Policy, 35(9), 1377 1388 .

Janjić, I., Ranđenović, T. (2019). The importance of managing innovations in modern enterprises. Ekonomika, 65(3), 45-54.

Jovanović, M., Petrović, B., Janjić, I. (2021). Key determinants of sustainable intellectual capital of enterprises. Economics of Sustainable Development, 5(1), 1-10.

Katila, R., Ahuja, G. (2002). Something old, something new: A longitudinal study of search behavior and new product introduction. Academy of Management Journal, 45(6), 1183-1194. 
Krstić, B., Rađenović, T. (2019). Intelektualni kapital i konkurentnost-mikro i makro aspekt. Niš: Ekonomski fakultet.

Laursen, K., Salter, A. (2006). Open for Innovation: The Role of Openness in Explaining Innovation Performance among U.K. Manufacturing Firms. Strategic Management Journal, 27(2), 131-150.

Mansfield, E. (1980). Basic Research and Productivity Increase in Manufacturing. American Economic Review, 70(5), 863-873.

Marković, M., Krstić, B., Rađenović, T. (2020). Circular economy and sustainable development. Economics of Sustainable Development, 4(2), 1-9.

Mathews, J.A. (2003). Strategizing by firms in the presence of markets for resoures. Industrial and Coprorate Change, 12(6), 1157-1193.

Nieto, M. (2001). Bases para el Estudio del Proceso de Innovación Tecnológica en la Empresa. León: Universidad de León.

Pakes, A., Griliches, Z. (1984). Patents and R\&D at the Firm Level: A First Look. In: Griliches, Z. (Ed.). Patents and Productivity, Chicago: University of Chicago Press, 55-72.

Petković, M., Krstić, B., Rađenović, T. (2020). Accounting-based valuation methods of intangible assets: Theoretical overview. Ekonomika, 66(1), 1-12.

Romer, P.M. (1990). Endogenous technological change. Journal of Political Economy, 98(5), 71-102.

Tether, B.S. (2005). The Role of Design in Business Performance. DTI Think Piece. CRIC: University of Manchester.

Tsai, K.H. (2005). R\&D Productivity and Firm Size: A Nonlinear Examination. Technovation, 25(7), 795-803.

Wakasugi, R., Koyata, F. (1997). R\&D, firm size and innovation outputs: are japanese firms efficient in product development. Journal of Product Innovation and Management, 14(5), 383-392.

WIPO. (2020). Global Innovation Index 2020 - Who Will Finance Innovation? Cornel: SC Johnson College of Business. 